\title{
HUBUNGAN AKREDITASI SEKOLAH, HASIL UJIAN NASIONAL, DAN INDEKS INTEGRITAS UJIAN NASIONAL
}

\section{THE RELATIONSHIP BETWEEN SCHOOL ACCREDITATION, NATIONAL EXAM RESULTS, AND INTEGRITY INDEX OF NATIONAL EXAM}

\author{
Asrijanty \\ Pusat Penilaian Pendidikan, Badan Penelitian dan Pengembangan \\ Kementerian Pendidikan dan Kebudayaan \\ E-mail: asrijanty@kemdikbud.go.id
}

Naskah diterima tanggal: 15-01-2018, disetujui tanggal: 14-12-2018

\begin{abstract}
The study examines the relationship between school accreditation, National Exam (NE) results, and Integrity Index of National Exam (IINE). The data for the school accreditation were accreditation scores of SMP/MTs by Accreditation National Board for Schools/Madrasah (BAN S/M) in 2010-2014. Data of NE and IINE were NE results in 2014/ 2015. The subject of this study was 14,248 schools. This study shows there was a positive correlation between school accreditation and NE scores. The correlation was increased when IINE was controlled. However, the correlation index was not high. It is understandable because school factor is one among other factors influencing student academic achievement. Other factors namely student's mindset and student's behavior are other significant factors determining student's academic achievement. Therefore, efforts to increase student achievement need to be carried out by increasing student engagement and increasing the quality of school.
\end{abstract}

Keywords: National Standard of Education, School Accreditation, National Exam, Integrity Index of National Exam

\begin{abstract}
Abstrak: Penelitian ini mengkaji hubungan antara akreditasi sekolah, hasil Ujian Nasional (UN), dan Indeks Integritas Ujian Nasional (IIUN). Data hasil akreditasi sekolah pada penelitian ini ialah nilai akreditasi sebagian SMP/MTs yang diakreditasi oleh Badan Akreditasi Nasional Sekolah/Madrasah (BAN S/M) tahun 2010-2014. Data nilai UN dan IIUN yang digunakan ialah hasil UN tahun pelajaran 2014/2015. Subjek penelitian ini ialah 14.248 sekolah. Hasil penelitian menunjukkan adanya hubungan yang positif antara hasil akreditasi sekolah dan hasil UN. Hubungan kedua variabel menguat ketika IIUN dikontrol. Meskipun demikian, indeks korelasi yang diperoleh tidak tinggi. Hal ini dapat dipahami karena faktor sekolah hanya merupakan salah satu faktor yang memengaruhi prestasi siswa. Faktor lain seperti mindset siswa dan perilaku siswa merupakan faktor penting lain yang memengaruhi prestasi siswa. Oleh karena itu, upaya untuk meningkatkan prestasi siswa perlu dilakukan dengan meningkatkan keterlibatan siswa dalam proses belajar dan meningkatkan kualitas sekolah.
\end{abstract}

Kata kunci: Standar Nasional Pendidikan, Akreditasi Sekolah, Ujian Nasional, Indeks Integritas Ujian Nasional 


\section{PENDAHULUAN}

Evaluasi terhadap sekolah pada dasarnya merupakan kegiatan yang dilakukan untuk menjamin mutu sekolah dalam pelaksanaan tugasnya mendidik siswa. Faubert (2009) dalam ulasannya terhadap pelaksanaan evaluasi sekolah pada negara-negara yang tergabung dalam OECD (Organisation for Economic Cooperation and Development) mengidentifikasi dua tujuan evaluasi sekolah yaitu untuk perbaikan dan akuntabilitas. Evaluasi terhadap sekolah dengan tujuan perbaikan untuk meningkatkan performa seluruh siswa dan sekaligus mengurangi kesenjangan antara sekolah yang berkinerja tinggi dan berkinerja rendah. Fungsi akuntabilitas sebagai bentuk pertanggungjawaban sekolah dalam penyelenggaraan pendidikan.

Di Indonesia, evaluasi terhadap satuan pendidikan dilakukan melalui kegiatan akreditasi. Menurut Peraturan Pemerintah Republik Indonesia Nomor 19 Tahun 2005 tentang Standar Nasional Pendidikan, akreditasi merupakan kegiatan penilaian kelayakan program dan/atau satuan pendidikan berdasarkan kriteria yang telah ditetapkan. Kebijakan akreditasi ini berdasarkan pemikiran bahwa setiap warga negara berhak memperoleh pendidikan yang bermutu. Untuk dapat menyelenggarakan pendidikan yang bermutu, setiap satuan/ program pendidikan harus memenuhi atau melampaui standar yang dilakukan melalui kegiatan akreditasi terhadap kelayakan setiap satuan/program pendidikan (Kementerian Pendidikan Nasional, 2011)

Pada jenjang pendidikan dasar dan menengah, akreditasi dilaksanakan oleh Badan Akreditasi Nasional Sekolah/Madrasah (BAN S/ M) dengan menggunakan delapan Standar Nasional Pendidikan (SNP) sebagai acuan penilaian. Hasil penilaian pada setiap standar menentukan nilai akhir dan peringkat akreditasi suatu satuan pendidikan. Peringkat akreditasi dikelompokkan menjadi tiga yaitu peringkat akreditasi A, sangat baik (nilai 86-100), B, Baik (nilai 71-85), dan C, Cukup Baik (nilai 56-70). Sekolah yang tidak memenuhi seluruh syarat akreditasi dinyatakan Tidak Terakreditasi (TT).

Hasil akreditasi sekolah/madrasah bermanfaat sebagai: 1) acuan dalam upaya peningkatan mutu dan rencana pengembangan sekolah/madrasah; 2) umpan balik dalam usaha pemberdayaan dan pengembangan kinerja warga sekolah/madrasah dalam rangka menerapkan visi, misi, tujuan, sasaran, strategi, dan program sekolah/madrasah; 3) motivator agar sekolah/madrasah terus meningkatkan mutu pendidikan secara bertahap, terencana, dan kompetitif baik di tingkat kabupaten/kota, provinsi, nasional bahkan regional dan internasional; 4) bahan informasi bagi sekolah/ madrasah untuk mendapatkan dukungan dari pemerintah, masyarakat, maupun sektor swasta dalam hal profesionalisme, moral, tenaga, dan dana; dan 5) acuan bagi lembaga terkait dalam mempertimbangkan kewenangan sekolah/ madrasah sebagai penyelenggara ujian nasional (Badan Akreditasi Nasional Sekolah/Madrasah, 2014). Karena peringkat akreditasi mencerminkan mutu sekolah, diharapkan ada hubungan antara akreditasi sekolah dan prestasi belajar peserta didik. Prestasi peserta didik yang berasal dari sekolah dengan peringkat akreditasi tinggi diharapkan lebih baik daripada peserta didik dari sekolah dengan peringkat akreditas lebih rendah. Namun beberapa studi tidak mendukung hal ini.

Studi yang dilakukan oleh Raharjo (2014) terhadap 210 sekolah pada 45 kabupaten/kota di 23 provinsi menunjukkan ada hubungan antara nilai akreditasi dan nilai ujian nasional (UN) peserta didik, dengan koefisien sebesar 0,474. Namun hanya satu standar saja yaitu standar pendidik dan tenaga kependidikan yang memberikan kontribusi signifikan terhadap hubungan tersebut. Koefisien sebesar 0,474 menunjukkan $22,5 \%$ variasi nilai UN ditentukan oleh nilai akreditasi sekolah, dan $77,5 \%$ oleh 
faktor lain. Pada studi ini tidak dilaporkan ratarata nilai sekolah pada tiap peringkat akreditasi sehingga perbandingan nilai pada tiap peringkat akreditasi tidak dapat dilakukan. Namun, mencermati sebaran sekolah terakreditasi pada kuantil 1-5 (pengelompokkan nilai UN dalam 5 kelompok: K1: $\leq 7,0501 ; \mathrm{K} 2:$ 7,0501-7,6700; K3: 7,6701-8,0900; K4: 8,0901-8,3800; dan $\mathrm{K} 5 \geq 8,3800$ ) tampak adanya pola yang tidak diharapkan. Sekolah terakreditasi A dan B tersebar pada semua kuantil. Pada kuantil 1, terdapat $42 \%$ sekolah terakreditasi A, 36\% terakreditasi B, dan $22 \%$ terakreditasi C. Pada kuantil 2, terdapat $62 \%$ sekolah terakreditasi A, $26 \%$ terakreditasi B, dan $12 \%$ terakreditasi C. Pada kuantil 3, terdapat $58 \%$ sekolah terakreditasi A, 34\% terakreditasi B, dan 8\% terakreditasi C. Jumlah sekolah terakreditasi B lebih banyak di kuantil 3 daripada di kuantil 2 . Jumlah sekolah terakreditasi A lebih banyak di kuantil 2 daripada di kuantil 3. Hal tersebut menunjukkan pola yang tidak diharapkan karena semakin tinggi peringkat akreditasi diharapkan semakin tinggi proporsi atau jumlah sekolah yang memperoleh nilai UN lebih tinggi.

Studi yang dilakukan oleh Hidayati dan Budiyono (2015) pada skala lebih kecil, yaitu 16 SMP swasta pada kabupaten Banjarnegara menunjukkan rata-rata nilai UN sekolah terakreditasi A sebesar 5,83, terakreditasi B sebesar 4,02, dan sekolah yang terakreditasi $C$ sebesar 4,42. Hasil penelitian ini menunjukkan rata-rata nilai UN sekolah terakreditasi C lebih tinggi daripada yang terakreditasi B. Hal tersebut menunjukkan suatu pola yang tidak diharapkan.

Ujian nasional telah lama menjadi isu nasional. Salah satu aspek yang menjadi sorotan dan perbincangan publik adalah adanya indikasi kecurangan yang terjadi dalam pelaksanaan ujian nasional. Nilai UN sebagian siswa disinyalir bukan murni capaian siswa tetapi merupakan hasil bantuan terhadap siswa, baik dengan membiarkan siswa mencontek dalam pe- laksanaan ujian maupun adanya usaha memberi jawaban soal ujian (Mulyadi, 2007; Fitri, 2007).

Pada tahun 2015 Kementerian Pendidikan dan Kebudayaan (Kemendikbud) melakukan terobosan dengan menerbitkan Indeks Integritas Pelaksanaan Ujian Nasional (IIUN). Indeks yang dilaporkan dalam skala 0-100 menunjukkan tingkat indikasi kecurangan pada sekolah. Semakin rendah indeks, semakin kuat indikasi adanya kecurangan di suatu sekolah. Kemendikbud mengirimkan laporan IIUN kabupaten/kota kepada daerah provinsi dan kabupaten/kota. Dalam penyampaian hasil UN kepada dinas pendidikan provinsi, Pusat Penilaian Pendidikan melaporkan jumlah sekolah terindikasi melakukan kecurangan dalam pelaksanaan ujian nasional cukup signifikan (Kementerian Pendidikan dan Kebudayaan, 2015a; 2015b).

Bila kecurangan dalam pelaksanaan ujian nasional memang terjadi, maka nilai UN yang dihasilkan akan lebih tinggi daripada nilai yang sebenarnya. Bila dikaitkan dengan hasil studi yang dikutip terdahulu maka tidak konsistennya pola hubungan antara peringkat akreditasi dan nilai UN dapat terjadi karena nilai UN sebagai variabel dependen tidak sepenuhnya valid.

Ketika suatu variabel dependen tidak menggambarkan keadaan yang sesungguhnya maka kesimpulan yang ditarik dari analisis yang melibatkan variabel tersebut menjadi tidak valid pula. Dalam hal hubungan akreditasi sekolah dan prestasi belajar peserta didik, lemahnya hubungan antara kedua variabel itu dapat menyebabkan kepercayaan terhadap manfaat akreditasi menjadi berkurang. Padahal, akreditasi diharapkan berfungsi sebagai ukuran mutu sekolah.

Berdasarkan uraian dan permasalahan di atas maka perlu melihat kembali hubungan hasil akreditasi dan hasil ujian nasional dengan mempertimbangkan IIUN. Apakah sekolah dengan nilai akreditasi lebih tinggi menunjukkan 
nilai UN lebih tinggi? Apakah IIUN mempunyai andil terhadap hubungan hasil akreditasi dan hasil UN? Studi ini bertujuan mengkaji hubungan kedua variabel dengan IIUN sebagai variabel moderator.

\section{Akreditasi Sekolah/Madrasah}

Menurut Undang-Undang Nomor 20 tahun 2003 tentang Sistem Pendidikan Nasional, akreditasi adalah kegiatan penilaian kelayakan program dan/atau satuan pendidikan berdasarkan kriteria yang telah ditetapkan. Kriteria tersebut mengacu pada Standar Nasional Pendidikan (SNP), yaitu: 1) standar isi; 2) standar proses; 3) standar kompetensi lulusan; 4) standar pendidik dan tenaga kependidikan; 5) standar sarana dan prasarana; 6) standar pengelolaan; 7) standar pembiayaan; dan 8) standar penilaian pendidikan.

Data akreditasi yang dianalisis pada studi ini merupakan hasil akreditasi tahun 2010-2014 menggunakan kriteria dan perangkat akreditasi yang berlaku pada saat itu. Saat ini, telah dikembangkan perangkat akreditasi yang baru. Kriteria dan perangkat akreditasi yang digunakan pada studi ini berdasarkan Peraturan Menteri Pendidikan Nasional (Permendiknas). Untuk setiap jenjang pendidikan diatur dalam Permendiknas tersendiri. Untuk SMP/MTs, kriteria dan perangkat akreditasi diatur pada Peraturan Menteri Pendidikan Nasional Nomor 12 tahun 2009 tentang Kriteria dan Perangkat Akreditasi SMP/MTs .

Menurut Permendiknas Nomor 12 Tahun 2009, sekolah/madrasah dinyatakan terakreditasi jika memenuhi seluruh kriteria berikut: 1) Memperoleh nilai akhir akreditasi sekurangkurangnya 56; 2) Tidak lebih dari dua nilai komponen akreditasi skala ratusan kurang dari 56; 3) Tidak ada nilai komponen akreditasi skala ratusan kurang dari 40 . Nilai maksimum yang mungkin dicapai ialah 100. Sekolah/Madrasah dinyatakan Tidak Terakreditasi (TT), jika berdasarkan hasil penilaian tim asesor, ketiga kriteria tersebut di atas tidak terpenuhi.

Peringkat akreditasi sekolah/madrasah terakreditasi dibedakan dalam tiga kelompok seperti tampak pada Tabel 1.

Tabel 1 Peringkat dan Nilai Akreditasi

\begin{tabular}{ll}
\hline Peringkat & Nilai Akhir Akreditasi \\
\hline A (Sangat Baik) & $86-100$ \\
B (Baik) & $71-85$ \\
C (Cukup Baik) & $56-70$ \\
\hline
\end{tabular}

\section{Ujian Nasional}

Ujian nasional (UN) sebagai bentuk penilaian yang dilakukan oleh Pemerintah telah mengalami beberapa kali perubahan. Hal ini tercermin pada perubahan Peraturan Pemerintah (PP) tentang Standar Nasional Pendidikan yang mengatur hal tersebut. Pada Peraturan Pemerintah Nomor 19 tahun 2005 tentang Standar Nasional Pendidikan terdapat empat fungsi Ujian Nasional yaitu 1) pemetaan mutu program dan/atau satuan pendidikan; 2) pertimbangan seleksi masuk jenjang pendidikan berikutnya; 3 ) penentuan kelulusan peserta didik dari program dan/atau satuan pendidikan; 4) pembinaan dan pemberian bantuan kepada satuan pendidikan dalam upayanya untuk meningkatkan mutu pendidikan. Berdasarkan PP tersebut UN diselenggarakan pada jenjang SD/MI, SMP/MTs, SMK, dan SMA/MA dan yang sederajat.

Pada tahun 2013, dilakukan perubahan pada PP Nomor 19 tahun 2005 sehingga terbit Peraturan Pemerintah Nomor 32 tahun 2013. Perubahan yang berkaitan dengan UN antara lain UN pada jenjang SD/MI ditiadakan sehingga UN hanya diselenggarakan mulai jenjang SMP ke atas. Perubahan terhadap PP tentang Standar Nasional Pendidikan kembali dilakukan pada tahun 2015, dengan diterbitkannya Peraturan Pemerintah Nomor 13 tahun 2015. Pada PP tersebut fungsi atau pemanfaatan UN yang ketiga yaitu penentuan kelulusan peserta didik 
dari program dan/atau satuan pendidikan ditiadakan. Dengan demikian peserta didik yang memeroleh nilai rendah pada ujian nasional tetap dapat lulus dari satuan pendidikan sepanjang persyaratan lain terpenuhi. Fungsi UN yang lain, seperti pertimbangan seleksi masuk ke jenjang pendidikan tetap berlaku.

Pada tahun 2015 perubahan UN tidak hanya pada dihilangkannya fungsi UN sebagai salah satu faktor penentu kelulusan dari satuan pendidikan, tetapi juga dengan diterbitkannya Indeks Integritas Pelaksanaan Ujian Nasional. Indeks Integritas Pelaksanaan UN (IIUN) setiap kabupaten/kota dilaporkan kepada kepala daerah dan juga pada media massa. Pelaporan IIUN tersebut memberi pesan tegas bahwa hal yang perlu ditekankan kepada semua pihak adalah berlaku jujur; bahwa memperoleh nilai tinggi dengan cara-cara yang curang tidak dikehendaki.

Pada tahun 2015 juga dimulainya pelaksanaan UN dengan menggunakan komputer (UNBK). Penggunaan UNBK merupakan usaha pemerintah untuk melaksanakan UN secara efisien dan kredibel. Masalah kecurangan, kebocoran, biaya yang sangat besar untuk pencetakan, pendistribusian naskah yang selama ini muncul pada ujian yang berbasis kertas dapat diatasi dengan UNBK.

\section{Indeks Integritas Pelaksanaan Ujian Nasional}

Indeks Integritas Pelaksanaan Ujian Nasional (IIUN) merupakan indikasi kecurangan yang terjadi pada pelaksanaan UN pada suatu sekolah. Indeks tersebut dikembangkan oleh tim analisis Pusat Penilaian Pendidikan Kemendikbud pada tahun 2015.

Seperti telah dikemukakan sebelumnya IIUN dilaporkan dalam skala 0-100. Semakin rendah indeks, semakin kuat indikasi adanya kecurangan di suatu sekolah. IIUN pada tingkat kabupaten/kota dapat ditentukan dengan menggunakan rata-rata IIUN sekolah yang berada pada kabupaten/kota tersebut, demikian pula IIUN tingkat provinsi dihitung berdasarkan rata-rata IIUN sekolah pada tingkat provinsi.

Indeks Integritas yang dikembangkan oleh tim analisis Pusat Penilaian Pendidikan Kemendikbud, merupakan indeks yang diperoleh dari gabungan dua metode. Kedua metode tersebut yaitu metode untuk mendeteksi kecurangan yang terjadi antarindividu dan metode untuk mendeteksi pola kecurangan yang terjadi secara sistematis pada suatu kelompok. Kecurangan antarindividu terjadi misalnya ketika siswa melihat jawaban teman, saling bertanya atau bertukar jawaban antarsiswa. Metode yang digunakan untuk mendeteksi kecurangan ini disebut metode pairwise, yaitu metode dengan membandingkan respon siswa satu dengan siswa lainnya. Kecurangan sistematis terjadi ketika ada penyebaran atau pembocoran kunci jawaban kepada satu kelompok peserta ujian. Kelompok tersebut dapat berupa peserta yang berada di suatu ruang ujian, di suatu sekolah atau di suatu wilayah. Metode yang digunakan untuk mendeteksi kecurangan tersebut yaitu metode kumulatif, yaitu dengan menganalisis keseragaman pola dalam satu sekolah atau wilayah (Kementerian Pendidikan dan Kebudayaan, 2015c).

\section{METODE}

Data dalam penelitian ini terdiri dari data UN SMP/MTs tahun pelajaran 2014/2015 dan IIUN sekolah tahun pelajaran 2014/2015. Data diperoleh dari Pusat Penilaian Pendidikan Balitbang Kemendikbud serta data akreditasi SMP/MTs tahun 2010-2014 dari BAN S/M. Data SMP/MTs yang diperoleh dari dari BAN S/M sejumlah 24798 sekolah SMP/MTs, namun hanya 14.248 yang dianalisis pada studi ini. Data sebagian sekolah yang tidak dianalisis karena kurang lengkap informasi pada sebagian sekolah, terutama tidak adanya identitas khusus sekolah seperti NPSN (Nomor Pokok Sekolah Nasional) sehingga proses mencocokkan (matching) 
dengan data UN sulit dilakukan. Variabel penelitian pada studi ini terdiri dari tiga variabel yaitu nilai akreditasi sebagai variabel independen, nilai UN sebagai variabel dependen, dan IIUN sebagai variabel moderator. Nilai akreditasi merupakan nilai dari delapan standar penilaian. Nilai UN merupakan nilai rata-rata dari empat mata pelajaran di SMP yaitu Bahasa Indonesia, Bahasa Inggris, Matematika, dan IPA. Rentang nilai kedua variabel ialah 0-100. Untuk akreditasi, pelaporan dalam dua bentuk yaitu nilai dan peringkat yaitu $A, B, C$, dan $T$ (tidak terakreditasi).

IIUN merupakan indeks yang menunjukkan tingkat indikasi kecurangan pada sekolah pada saat pelaksanan UN. Dengan rentang 0-100, IIUN dalam penelitian ini dikelompokkan dalam tiga kategori: 1) tinggi, bila indeks lebih besar dari 70; 2) sedang, bila indeks antara 50-70; dan 3) rendah, bila indeks di bawah 50.

Analisis dilakukan untuk melihat hubungan antara nilai UN, nilai akreditasi, dan IIUN. Oleh karena itu, dua jenis analisis dilakukan yaitu analisis korelasi nilai UN dan nilai akreditasi pada tiap kelompok IIUN dan analisis regresi dengan tiga variabel. Analisis dilakukan dengan menggunakan program SPSS versi 22. Mengingat data yang cukup besar dan mempertimbangkan signifikansi korelasi ditentukan oleh besarnya data (semakin besar data, kemungkinan korelasi signifikan semakin tinggi meskipun indeks korelasi rendah), maka analisis regresi dilakukan dengan menggunakan 3 data set yaitu: 100\% data (14248 sekolah), 50\% data (7101 sekolah), dan $25 \%$ data (2853 sekolah). Pemilihan data dilakukan secara random dengan program SPSS. Analisis dengan 3 data set ini berfungsi sebagai validasi hasil sehingga informasi konsistensi hasil dapat diperoleh.

\section{HASIL DAN PEMBAHASAN}

\section{Distribusi dan Statistik Nilai UN dan Nilai Akreditasi}

Seperti telah dikemukakan sebelumnya rentang nilai UN dan nilai akreditasi ialah 0-100. Distribusi untuk kedua variabel tersebut disajikan pada Gambar 1. Nilai akreditasi cenderung condong ke kiri (negatively skewed) sementara nilai UN relatif normal. Hal tersebut menunjukkan lebih banyak sekolah yang memperoleh nilai akreditasi tinggi. Hal ini dapat dimengerti, banyaknya komponen yang dinilai hampir tidak mungkin sekolah memperoleh nilai akreditasi yang sangat rendah. Dari 14.248 sekolah yang dianalisis terdapat 4.920 sekolah $(34,5 \%)$ yang nilai akreditasi di atas 85 (peringkat $A$ ), 6794 sekolah $(47,7 \%)$ dengan nilai $71-85$ (peringkat B) dan 2.231 sekolah $(15,7 \%)$ dengan nilai $56-70$ (peringkat C), dan sejumlah 303 sekolah $(2,1 \%)$ yang dikategorikan Tidak Terakreditasi (TT)

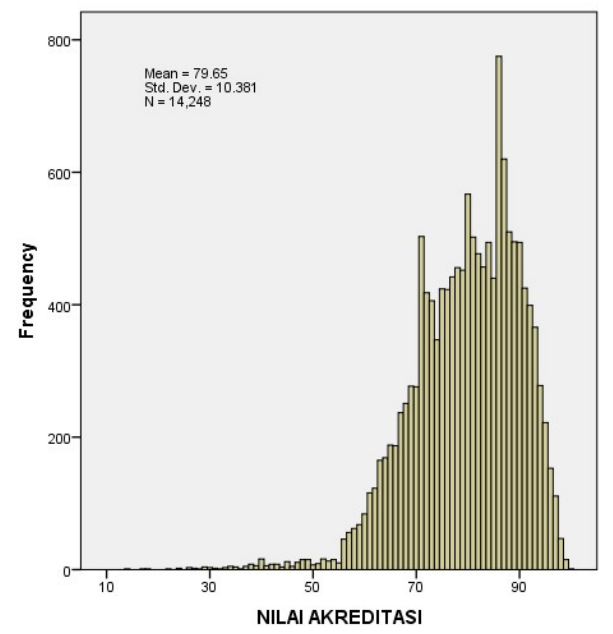

Gambar 1 Distrisbusi Nilai UN dan Nilai Akreditasi 
karena tidak terpenuhinya syarat yang ditetapkan.

Idealnya sekolah yang berakreditasi A diharapkan memperoleh nilai UN lebih tinggi daripada sekolah yang berakreditasi dengan predikat lebih rendah. Namun, data tidak menunjukkan pola ini. Seperti dapat dilihat pada Gambar 2, distribusi nilai untuk keempat kategori akreditasi tidak menunjukkan perbedaan yang siginifikan, baik rentang nilai minimum, maksimum maupun bentuk distribusi.
Bila dilihat statistik nilai secara detil pada Tabel 2 tampak bahwa perbedaan nilai antara ketiga peringkat akreditasi $(A, B, C)$ sangat kecil terutama perbedaan nilai antara peringkat $B$ dan peringkat C. Rata-rata nilai UN peringkat B ialah 59,91 sementara rata-rata nlai UN untuk peringkat $C$ ialah 60.01. Hal ini menunjukkan hampir tidak adanya perbedaan antara dua kelompok tersebut. Padahal diharapkan sekolah dengan peringkat akreditasi lebih rendah akan menunjukkan capaian nilai UN secara signifikan

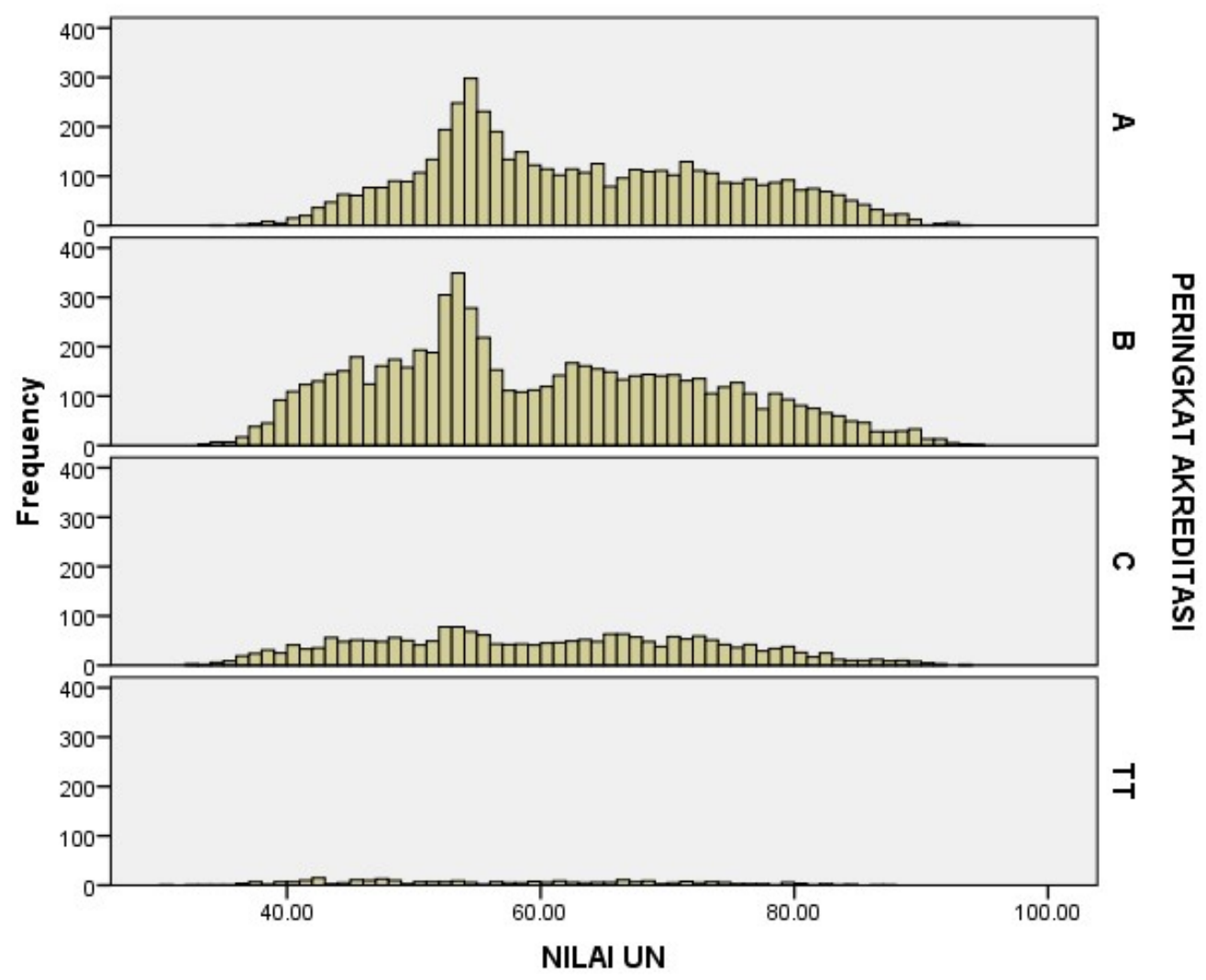

Gambar 2 Distribusi Nilai UN berdasarkan Peringkat Akreditasi

Tabel 2 Nilai UN berdasarkan Peringkat Akreditasi

\begin{tabular}{lllllll}
\hline Akreditasi & N & Min & Maks & Med & Mean & Std Dev \\
\hline A & 4920 & 34.1 & 93.5 & 60.5 & 62.7 & 11.7 \\
B & 6794 & 33.1 & 94.9 & 57.4 & 59.9 & 12.9 \\
C & 2231 & 32.1 & 93.4 & 59.6 & 60.1 & 13.2 \\
TT & 303 & 30.6 & 87.1 & 56.2 & 57.0 & 13.2 \\
\hline Total & 14248 & 30.6 & 94.9 & 59.1 & 60.8 & 12.6 \\
\hline
\end{tabular}


lebih rendah daripada sekolah dengan peringkat yang lebih tinggi.

\section{Distribusi dan Statistik Nilai UN, Peringkat Akreditasi, dan IIUN}

Hasil yang dikemukakan sebelumnya belum memasukkan variasi IIUN. Untuk melihat hubungan ketiga varibel, data dikelompokkan tidak hanya berdasarkan peringkat akreditasi tetapi juga berdasarkan kelompok IIUN. Distribusi nilai UN untuk setiap kategori IIUN pada masingmasing peringkat akreditasi disajikan pada Gambar 3, sedangkan statistik nilai disajikan pada Tabel 3.

Gambar 3 dan Tabel 3 menunjukkan pada kelompok IIUN rendah nilai UN lebih tinggi secara signifikan daripada kelompok IIUN sedang dan IIUN tinggi. Bahkan nilai UN pada sekolah dengan peringkat akreditasi $\mathrm{C}$ dan $\Pi$ (tidak terakreditasi) pada kolompok IIUN rendah jauh lebih tinggi daripada nilai UN sekolah dengan peringkat akreditasi A pada kelompok IIUN tinggi. Nilai UN yang secara konsisten tinggi untuk semua peringkat akreditasi pada kelompok IIUN rendah menguatkan indikasi bahwa nilai tersebut tidak menggambarkan capaian yang sesungguhnya.

\section{Hubungan Nilai UN dan Nilai Akreditasi}

Hasil analisis yang dilakukan untuk melihat hubungan antara nilai UN dan nilai akreditasi dengan memperhitungkan IIUN sebagai variabel moderator. Analisis pertama dilakukan dengan analisis korelasi nilai UN dan nilai akreditasi pada tiap kelompok IIUN; analisis kedua dengan analisis regresi tiga variabel. Analisis regresi dilakukan pada tiga set data: $100 \%$ data (14248 sekolah), 50\% data (7101 sekolah), dan 25\% data (2853 sekolah) untuk melihat konsistensi hasil.

\section{KATEGORI IIUN}

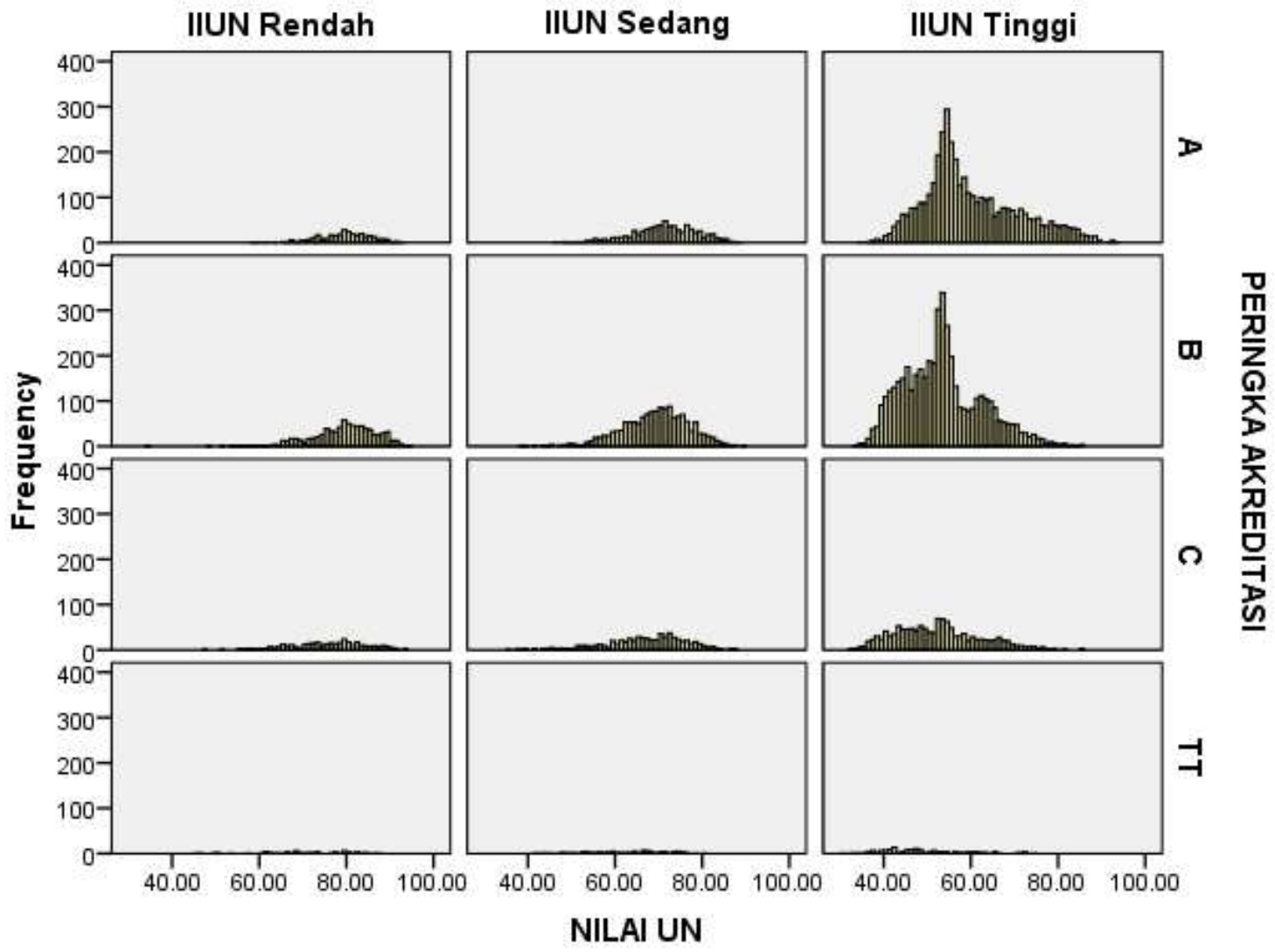

Gambar 3 Distribusi Nilai UN berdasarkan Peringkat Akreditasi dan Katgeori IIUN 
Tabel 3 Nilai UN Berdasarkan Kategori IIUN dan Peringkat Akreditasi

\begin{tabular}{|c|c|c|c|c|c|c|c|}
\hline KAT & Akreditasi & $\mathrm{N}$ & Min & Maks & Med & Mean & Std. Dev \\
\hline \multirow{5}{*}{$\begin{array}{c}\text { IIUN } \\
\text { Rendah }\end{array}$} & A & 301 & 59 & 92.3 & 79.8 & 79.5 & 6.0 \\
\hline & B & 800 & 34.5 & 94.9 & 80.2 & 79.4 & 7.5 \\
\hline & C & 340 & 47.1 & 93.4 & 76.8 & 76.1 & 8.4 \\
\hline & TT & 59 & 45.3 & 87.1 & 70.3 & 70.4 & 10.5 \\
\hline & Total & 1500 & 34.5 & 94.9 & 79.4 & 78.3 & 7.9 \\
\hline \multirow{5}{*}{$\begin{array}{c}\text { IIUN } \\
\text { Sedang }\end{array}$} & A & 681 & 46.8 & 88.3 & 71.7 & 71.3 & 7.5 \\
\hline & B & 1466 & 38.5 & 89.1 & 69.9 & 69.3 & 7.6 \\
\hline & C & 618 & 35.6 & 87.9 & 68.2 & 67.1 & 9.3 \\
\hline & TT & 90 & 41.2 & 80.8 & 64.2 & 62.6 & 9.4 \\
\hline & Total & 2855 & 35.6 & 89.1 & 70.0 & 69.1 & 8.2 \\
\hline \multirow{5}{*}{$\begin{array}{c}\text { IIUN } \\
\text { Tinggi }\end{array}$} & $A$ & 3938 & 34.1 & 93.5 & 57.0 & 60.0 & 10.8 \\
\hline & B & 4528 & 33.1 & 86.0 & 52.8 & 53.4 & 9.1 \\
\hline & C & 1273 & 32.1 & 85.8 & 52.1 & 52.4 & 9.6 \\
\hline & $\mathrm{TT}$ & 154 & 30.6 & 74.2 & 46.7 & 48.5 & 9.4 \\
\hline & Total & 9893 & 30.6 & 93.5 & 54.2 & 55.8 & 10.4 \\
\hline \multirow{5}{*}{ Total } & $A$ & 4920 & 34.1 & 93.5 & 60.5 & 62.7 & 11.7 \\
\hline & B & 6794 & 33.1 & 94.9 & 57.4 & 59.9 & 12.9 \\
\hline & C & 2231 & 32.1 & 93.4 & 59.6 & 60.1 & 13.2 \\
\hline & $\mathrm{TT}$ & 303 & 30.6 & 87.1 & 56.2 & 57.0 & 13.2 \\
\hline & Total & 14248 & 30.6 & 94.9 & 59.1 & 60.8 & 12.6 \\
\hline
\end{tabular}

Tabel 4 menunjukkan pola hubungan yang diharapkan yaitu adanya korelasi positif antara nilai UN dan nilai akreditasi, dengan korelasi lebih tinggi ketika data yang digunakan semakin "bersih", yaitu data sekolah dengan IIUN tinggi. Dengan data keseluruhan indeks korelasi yang diperoleh sebesar 0,119, korelasi menjadi 0,341 ketika menggunakan data sekolah dengan IIUN tinggi.

Tabel 5 merupakan hasil analisis ketiga variabel dengan tiga data set yang menunjukkan adanya konsistensi hasil dari ketiga data set. Korelasi antara nilai UN dan IIUN cukup tinggi dengan arah berlawanan. Hal ini menunjukkan kecenderungan sekolah dengan IIUN rendah mencapai nilai UN tinggi dan sebaliknya. Indeks korelasi sebesar 0.63 antara nilai UN dengan dua prediktor (nilai akreditasi dan IIUN) karena besarnya sumbangan IIUN. Korelasi antara nilai UN dan nilai akreditasi meningkat ketika IIUN dikontrol, dari semula berkisar 0.12-0.14 menjadi 0.28-0.30. Hasil ini konsisten dengan hasil sebelumnya pada Tabel 4.

Hasil studi ini menunjukkan IIUN berfungsi sebagai variabel moderator, yaitu variabel yang memengaruhi kekuatan hubungan antara variabel independen dan variabel dependen. Dengan dimasukkannya IIUN dalam analisis,

Tabel 4 Korelasi Nilai UN dan Nilai Akreditasi Berdasar Kelompok IIUN

\begin{tabular}{lrrr}
\hline Kelompok & $\mathrm{N}$ & Korelasi & Signifikansi \\
\hline Total & 14248 & 0.119 & $<0.01$ \\
IIUN Rendah & 1500 & 0.231 & $<0.01$ \\
IIUN Sedang & 2855 & 0.224 & $<0.01$ \\
IIUN Tinggi & 9893 & 0.341 & $<0.01$ \\
\hline
\end{tabular}


Tabel 5 Korelasi Nilai UN, Nilai Akreditasi dan IIUN Pada Tiga Data Set

\begin{tabular}{llclll}
\hline Analisis & $\mathrm{N}$ & $\mathrm{r}$ Akreditasi-UN & $\mathrm{r}$ IIUN- UN & $\begin{array}{l}\mathrm{R}(2 \\
\text { prediktor } \\
\text { Akreditasi } \\
\text { \& IIUN) }\end{array}$ & $\begin{array}{l}\mathrm{r} \text { UN- } \\
\text { Akreditasi } \\
\text { kontrol IIUN }\end{array}$ \\
\hline Data $100 \%$ & 14250 & 0.119 & -0.589 & 0.631 & 0.278 \\
Data $50 \%$ & 7101 & 0.139 & -0.585 & 0.632 & 0.297 \\
Data $25 \%$ & 2853 & 0.129 & -0.580 & 0.624 & 0.284 \\
\hline
\end{tabular}

hubungan antara nilai akreditasi dan nilai UN menjadi semakin kuat. Hal ini mengindikasikan berfungsinya IIUN sebagai alat deteksi kecurangan dan sekaligus menunjukkan indikasi kecurangan terjadi terutama pada kelompok IIUN rendah. Bila kecurangan tidak terjadi dan IIUN tidak dapat mendeteksi adanya kecurangan, maka pola hubungan antara nilai akreditasi dan nilai UN akan sama pada tiap kelompok kategori IIUN. Pada hasil yang telah disajikan,sekolah pada kelompok IIUN rendah memperoleh nilai UN yang lebih tinggi daripada sekolah kelompok IIUN tinggi dan sedang.

Adanya hubungan yang positif antara nilai akreditasi dan nilai UN seperti yang diharapkan dan sesuai dengan yang ditunjukkan oleh hasilhasil studi terdahulu. Akreditasi mencerminkan capaian sekolah terhadap standar yang telah ditentukan, salah satunya adalah standar pendidik dan tenaga kependidikan. Beberapa studi menunjukkan pengaruh guru sangat besar terhadap prestasi siswa. Darling-Hammond (2000) melakukan studi menggunakan data dari 50 negara bagian Amerika Serikat yang mencakup survei, studi kasus, dan hasil National Assessment of Educational Progress (NAEP) untuk melihat hubungan kualitas guru dan school inputs terhadap prestasi belajar siswa. Hasil studi menunjukkan persiapan guru dan sertifikasi guru secara konsisten berkorelasi paling tinggi dengan prestasi siswa pada Matematika dan Membaca, baik sebelum maupun sesudah mengontrol tingkat kemiskinan siswa dan status bahasa. Hasil studi Clotfelter, Ladd dan Vigdor (2007) juga menunjukkan adanya pengaruh guru, khususnya pengalaman guru, kualifikasi guru dan hasil sertifikasi guru, terhadap prestasi siswa. Bahwa guru yang berpengalaman mempunyai pengaruh yang lebih baik terhadap capaian siswa, dibandingkan guru yang kurang berpengalaman, juga ditunjukkan oleh studi yang dilakukan Harris dan Sass (2011). Untuk mengidentifikasi secara spesifik pengaruh guru, Metzler dan Woessmann (2012) melakukan studi untuk melihat hubungan antara penguasaan materi oleh guru dengan prestasi siswa. Hasil studi menunjukkan adanya kenaikan pengetahuan guru diikuti dengan kenaikan prestasi siswa.

Korelasi nilai akreditasi dan nilai UN sekitar 0,34 pada studi ini menunjukkan $11,6 \%$ varian nilai UN diterangkan oleh nilai akreditasi. Hal ini menunjukkan meskipun kualitas sekolah mempunyai kontribusi dalam capaian UN namun bukan satu-satunya faktor. Faktor siswa baik internal individu seperti kecerdasan, motivasi maupun faktor di luar diri siswa seperti keluarga dapat mempengaruhi prestasi siswa.

Poropat (2009) dalam studinya menyimpulkan bahwa aspek kepribadian, terutama conscientiousness, yaitu mereka yang ingin melakukan tugas dengan baik, mengerjakan tugas dengan serius, mempunyai hubungan dengan performa akademis. Studi oleh Roksa dan Potter (2011) menunjukkan bahwa anakanak yang berasal dari tingkat sosial ekonomi menengah yang stabil mempunyai prestasi membaca dan Matematika yang lebih tinggi daripada anak-anak dari tingkat sosial ekonomi lebih rendah. Rogers, Theule, Ryan, Adams, \& Keating (2009) menunjukkan bahwa peran aktif orang tua dalam menciptakan lingkungan belajar 
yang kondusif mempunyai hubungan yang positif dengan kompetensi akademik siswa, yang selanjutnya memengaruhi prestasi belajar siswa di sekolah. Kompetensi akademik siswa yang dimaksud meliputi kemampuan akademik, sikap terhadap sekolah dan belajar, dan perilaku yang berorientasi belajar.

Masih mengenai hubungan prestasi dan faktor internal diri siswa, Schmakel (2008) menunjukkan siswa yang berprestasi tinggi lebih merasa tertantang dengan tugas sekolah dan mempunyai disiplin yang tinggi untuk belajar dan menyelesaikan tugas, dibandingkan siswa yang berprestai rendah. Penelitian McInerney, Cheng, Mok, dan Lam (2012) menunjukkan adanya hubungan positif antara konsep diri akademik, strategi belajar dan prestasi akademik pada Bahasa Inggris dan Matematika. Hattie (2009) berdasarkan kajiannya terhadap lebih dari 800 meta-analysis melaporkan ukuran pengaruh (effect size, disingkat $d$ ) beberapa faktor terhadap prestasi siswa. Ia mengelompokkan pengaruh tersebut dalam tiga kategori, yaitu rendah bila $\mathrm{d}=0,2$, sedang bila $\mathrm{d}=0,4$, dan tinggi bila $d=0,6$. Ukuran pengaruh kemampuan kognitif siswa terhadap prestasi sebesar 0,67, motivasi sebesar 0,48, status ekonomi keluarga dan lingkungan rumah, mempunyai ukuran pengaruh yang sama, yaitu sebesar 0,57.

Hasil analisis terhadap data Programme for International Student Assessment (PISA) tahun 2015 menguatkan hasil studi yang telah dikutip sebelumnya. Mourshed, Krawitz, dan Dorn (2017) menunjukkan faktor yang paling berpengaruh pada prestasi siswa adalah mindset siswa, yaitu sikap dan kepercayaan siswa secara umum terhadap mata pelajaran. Untuk siswa Asia, variasi prestasi siswa $31 \%$ ditentukan oleh perbedaan mindset siswa, $12 \%$ oleh perilaku siswa, 34\% ditentukan oleh faktor sekolah dan guru, $15 \%$ oleh lingkungan rumah, dan $9 \%$ oleh fakor lain. Hal ini menunjukkan prestasi siswa ditentukan oleh beberapa faktor; faktor sekolah dan faktor internal siswa merupakan dua faktor penting yang menentukan prestasi siswa.

Dalam studi untuk melihat hubungan hasil ujian nasional dan hasil akreditasi ini, penulis menyoroti validitas hasil ujian nasional sebagai variabel dependen. Hasil akreditasi sebagai variabel independen diasumsikan valid mencerminkan kualitas sekolah. Namun sebagaimana telah diakui para ahli pengukuran, pada tiap proses pengukuran terutama pada bidang sosial pengukuran tidaklah dapat sempurna, selalu ada kesalahan pengukuran (error of measurement) dengan derajat tertentu. Hal ini yang menjelaskan mengapa indeks korelasi tidak dapat tinggi (Nunnaly \& Bernstein, 1994). Data akreditasi yang dianalisis merupakan hasil akreditasi tahun 2010-2014 menggunakan perangkat akreditasi yang berlaku pada saat itu. Saat ini, telah dikembangkan perangkat akreditasi yang baru. Apabila data hasil akreditasi dengan perangkat baru dan data hasil ujian nasional yang berbasis komputer merupakan data dari hasil pengukuran yang lebih baik, yaitu mencerminkan keadaan yang mendekati sesungguhnya (kesalahan pengukuran yang lebih kecil) hubungan antara hasil ujian nasional dan hasil akreditasi menjadi lebih tinggi. Hubungan yang kuat antara akreditasi sekolah dan prestasi belajar siswa menguatkan posisi akreditasi sebagai ukuran mutu sekolah seperti yang diharapkan masyarakat pada umumnya.

\section{SIMPULAN DAN SARAN \\ Simpulan}

Simpulan dari studi ini ialah ada hubungan positif antara akreditasi sekolah dan hasil UN. Hubungan antara kedua variabel tersebut menjadi lebih kuat ketika IIUN dikontrol. Hal ini menunjukkan IIUN berfungsi sebagai alat deteksi kecurangan yang sekaligus menunjukkan indikasi kecurangan terjadi terutama pada kelompok IIUN rendah. Indeks korelasi akreditasi sekolah dan 
nilai UN ketika IIUN tidak dikontrol berkisar 0.120.14 (analisis dengan tiga data set); ketika IIUN dikontrol indeks korelasi meningkat menjadi 0.28-0.30. Korelasi yang tidak tinggi antara kedua variabel dapat dipahami mengingat sekolah hanya merupakan salah satu faktor yang memengaruhi prestasi siswa. Faktor lain seperti mindset siswa dan perilaku siswa merupakan faktor penting lain yang memengaruhi prestasi siswa.

\section{Saran}

Hasil studi ini menunjukkan adanya hubungan positif antara akreditasi sekolah dan nilai UN. Meskipun korelasi antara kedua variabel tersebut menguat ketika IIUN dikontrol, indeks korelasi tidak tinggi. Oleh karena faktor sekolah hanya merupakan salah satu faktor yang memengaruhi prestasi siswa maka upaya sekolah untuk meningkatkan prestasi perlu dilakukan dengan menguatkan kedua faktor dominan yang memengaruhi prestasi siswa yaitu faktor internal siswa dan faktor sekolah. Faktor internal siswa yang terutama dapat dipengaruhi ialah aspek nonkognitif siswa seperti sikap atau mindset siswa dan motivasi siswa. Siswa perlu mempunyai sikap yang positif terhadap belajar sehingga mempunyai motivasi untuk terlibat secara aktif dalam proses belajar, menjadi subjek yang bertanggung jawab terhadap proses belajarnya. Dengan pola pikir yang positif siswa dapat mengembangkan strategi belajar yang sesuai dengan kondisi dirinya. Usaha untuk meningkatkan sikap dan motivasi siswa merupakan hal yang penting. Di lain pihak, sekolah perlu terus meningkatkan kualitas sekolah, minimal seperti tercermin pada standar nasional pendidikan. Dengan demikian diharapkan terbangun iklim yang kondusif untuk siswa belajar.

Studi ini menggunakan data akreditasi tahun 2010-2014 dan hasil UN tahun pelajaran $2014 / 2015$. Analisis hubungan antara nilai UN dan akreditasi perlu dilakukan lagi dengan menggunakan data akreditasi yang terbaru yang menggunakan perangkat akreditasi yang berbeda, dan data UN yang terbaru sebagai hasil ujian nasional berbasis komputer.

\section{Ucapan Terima Kasih}

Penulis mengucapakan terima kasih kepada tim analisis Pusat Penilaian Pendidikan, khususnya Dr. Rahmawati dan Haryo Susetiyo, yang telah mengembangkan dan selanjutnya menganalisis data IIUN sekolah, serta Doddy Agung Santoso, yang telah melakukan matching data akreditasi dan UN sehingga analisis untuk melihat hubungan kedua variabel dapat dilakukan. Ucapan terima kasih juga kami sampaikan kepada Badan Akreditasi Nasional S/M khususnya Dr. Toni Toharudin, M.Sc dan Fajar Irfan untuk penyiapan data akreditasi sekolah.

\section{PUSTAKA ACUAN}

Badan Akreditasi Nasional Sekolah/Madrasah. (2014). Pedoman akreditasi: Akreditasi bermutu untuk pendidikan bermutu. Jakarta, BAN S/M.

Clotfelter, C.T., Ladd, H.F. \& Vigdor, J.L. (2007). How and why do teacher credentials matter for student achievement? Durham, NC: Duke University.

Darling-Hammond, L. (2000). Teacher quality and student achievement: A review of state policy evidence. Education Policy Analysis Archieves, 8(1), 1-44.

Faubert, V. (2009). School evaluation: Current practices in OECD countries and a literature review. OECD Education Working Papers, No. 42. OECD Publishing.

Fitri, S. (2007). Korban di altar persaingan global. Menggugat ujian nasional. Jakarta: Teraju (PT Mizan Pustaka). 
Harris, D.N. \& Sass, T. R. (2011). Teacher training, teacher quality, and student achievement. Journal of Public Economic, 95(7-8), 798-812.

Hattie, J. (2009). Visible learning: a synthesis of over 80 meta-analyses relating to achievement. New York: Routledge.

Hidayati, L. \& Budiyono. (2015). Hasil Ujian Nasional Matematika SMP Swasta di Kabupaten Banjarnegara ditinjau dari status akreditasi sekolah (Kasus Di Kabupaten Banjarnegara). Ekuivalen-Pendidikan Matematika, 15(1), 29-32.

Kementerian Pendidikan Nasional. (2011). Kajian Analisis Sistem Akreditasi Sekolah/Madrasah dalam Rangka Reformasi Birokrasi Internal. Jakarta: Kementerian Pendidikan Nasional

Kementerian Pendidikan dan Kebudayaan. (2015a). Paparan Kepala Pusat Penilaian Pendidikan dalam Penyampaian Hasil UN SMA/MA dan SMK tahun pelajaran 2014/2015 di Pusat Penilaian Pendidikan. Jakarta: Pusat Penilaian Pendidikan, Balitbang Kemendikbud.

Kementerian Pendidikan dan Kebudayaan. (2015b). Paparan Kepala Pusat Penilaian Pendidikan dalam Penyampaian Hasil UN SMP/MTs tahun pelajaran 2014/2015 di Pusat Penilaian Pendidikan. Jakarta: Pusat Penilaian Pendidikan, Balitbang Kemendikbud.

Kementerian Pendidikan dan Kebudayaan. (2015c). Laporan Hasil Ujian Nasional Tahun Pelajaran 2014/2015. Jakarta: Pusat Penilaian Pendidikan.

Kementerian Pendidikan Nasional. (2011). Kajian Analisis Sistem Akreditasi Sekolah/Madrasah dalam Rangka Reformasi Birokrasi Internal. Jakarta.

McInerney, D.M., Cheng, R.W., Mok, M.M.C. \& Lam, A.K.H. (2012). Academic self-concept( and learning strategies: Direction of effect on student academic achievement. Journal of Advanced Academics, 23(3), 249-269. https://doi.org/10.1177/1932202X12451020

Metzler, J. \& Woessmann, L. (2012). The impact of teacher subject knowledge on student achievement: Evidence from within-teacher within-student variation. Journal of Development Economics, 99(2), 486-496. https://doi.org/10.1016/j.jdeveco.2012.06.002

Mourshed, M., Krawitz, M. \& Dorn, E. (2017). How to improve student educational outcomes: New insights from data analytics. McKinsey \& Company Discussion Paper. https:// www.mckinsey.com/industries/social-sector/our-insights/how-to-improve-studenteducational-outcomes-new-insights-from-data-analytics, diakses 11 November 2018.

Mulyadi, S. (2007). Suara anak yang disenyapkan. Menggugat ujian nasional. Jakarta: Teraju (PT Mizan Pustaka).

Nunnaly, J.C. \& Bernstein, I.H. (1994). Psychometric theory (Third ed). New York: McGraw-Hill.

Peraturan Pemerintah Nomor 19 tahun 2005 tentang Standar Nasional Pendidikan.

Peraturan Menteri Pendidikan Nasional Nomor 12 tahun 2009 tentang Kriteria dan Perangkat Akreditasi SMP/MTs.

Peraturan Pemerintah Nomor 32 Tahun 2013 tentang Perubahan Atas Peraturan Pemerintah Nomor 19 tahun 2015 tentang Standar Nasional Pendidikan.

Peraturan Pemerintah Nomor 13 tahun 2015 tentang Perubahan Kedua Atas Peraturan Pemerintah Nomor 19 tahun 2015 tentang Standar Nasional Pendidikan.

Poropat, A.E. (2009). Meta-analysis of the five-factor model of personality and academic performance. Psychological Bulletin, 135(2), 322-338. 
Raharjo, S.B. (2014). Kontribusi delapan standar nasional pendidikan terhadap pencapaian prestasi belajar. Jurnal Pendidikan Dan Kebudayaan, 20(4), 470-482.

Rogers, M.A., Theule, J., Ryan, B.A., Adams, G.R. \& Keating, L. (2009). Parental involvement and children's school achievement: evidence for mediating processes. Canadian Journal of School Psychology, 24(1), 34-57.

Roksa, J. \& Potter, D. (2011). Parenting and academic achievement: Intergenerational transmission of educational advantage. Sociology of Education, 84(4), 299-321.

Schmakel, P.O. (2008). Early adolescents' perspectives on motivationand achievement in academics. Urban Education, 43(6), 723-749.

Undang-undang Nomor 20 Tahun 2003 tentang Sistem Pendidikan Nasional. 